317

2
$I-212$

0122

September 1, 1981

\author{
R. B. Rozsa \\ C. L. Hoenig
}

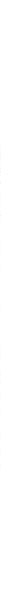




\title{
Synroc Processing Options
}

\author{
R. B. Rossa \\ C. L. Hoenig
}

Manuscript date: September 1, 1981

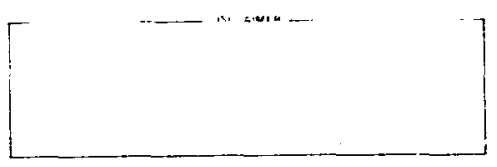

\section{LAWRENCE LIVERMORE LABORATORY}

Lniversity of California - Livermore. California - 94550 


\section{CONTENTS}

Abstract ..

Summary

Intruduction

Reference (ilan Prowens =

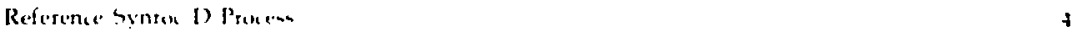

Mix ind Mill Stop 10

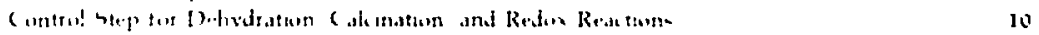

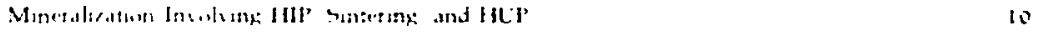

Retererace 11

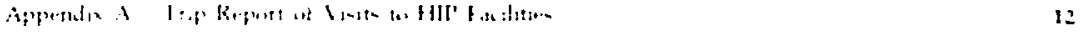




\title{
Synroc Processing Options
}

\begin{abstract}
Synroc is a titanate-based ceramic material currently being developed for immobilizing high-level nuclear reactor wastes in solid sorm. Synro: $D$ is a t:nique variation of Synroc. It can contain the high-level defense wastes. particularly those in storage at tive Savannah River Plant.

In this repors. we review the early development of the inital sinner process discuss modification and other options that simplify it overall. and recomsitend the future direetion of research and development in the proseseng areas

A reterence Syuroc procese is described bretly and contrasted with the bavan nati River Laboratory glas-based referene case. Preliminary engineereng lavout- how

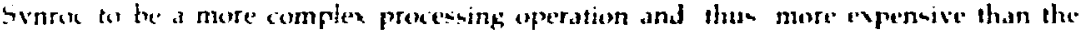

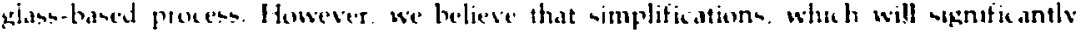

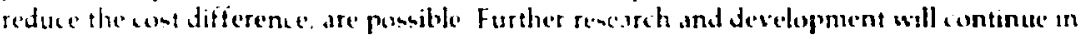

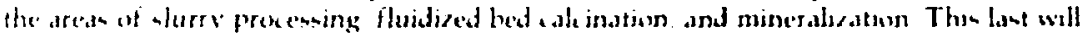

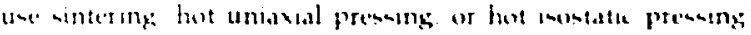

\section{SUMMARY}

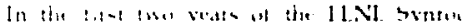

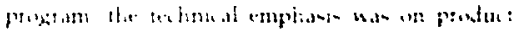

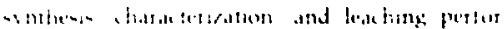

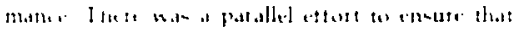

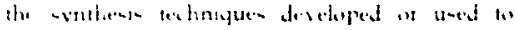

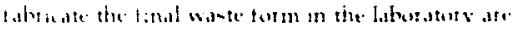

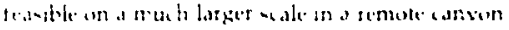

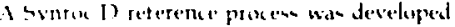
In the procen we empky a ball moll to prostuse s lune partale alurry a spray salenet to torm an

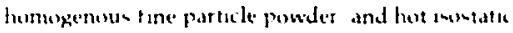

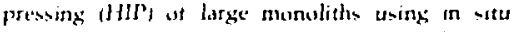
methode of redox-control with metal porvidere is preliminary engineering loyout and cost analyis made by the Savannah River Laboratory (SIRL। showed the base process cell of the Synrox syotem (1) cost approvinately twice that of the glass reterence-process cell and, thus, the overall Synroc processing plant to be about $50 \%$ more than the total cost of the glass plant.

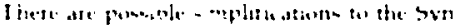

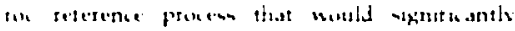

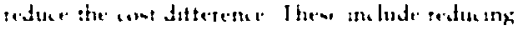

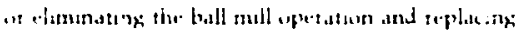

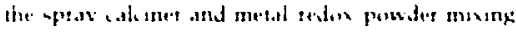

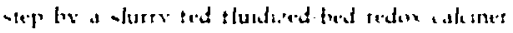

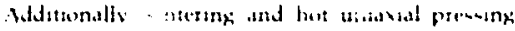

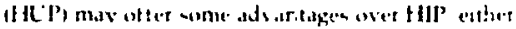

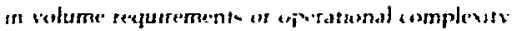

turtiner resedrah and develinpment in required to determane whether the - mplitis atron- would be pesible and to what extent the entprose the process In the continutng synaue program high prusity will be given to thene arede Equally impor tane are the areas of washing and of liquid and solid separatuon at the hedend to remuve hodium and silicon from the sludge. The pienence of fodium and ilicon produces a less resistant-to-leaching cesium host in the Synroc synthesis, and some research and development in reducing their presence is warranted. 


\section{INTRODUCTION}

Synroc. a titanate-based ceramic material, is presently being developed for immubilizing highlevel nuclear reactor wastes in wolid form ${ }^{t}{ }^{3}$ Synroc $D$. a unique variation of this waste form. will he able to contain high-level deferise waste, particularly those in storage at the Savannah River Plant Aikin $S C$ t.7 $^{\text {t. }}$ Currently there are thirse trpere of bynros te Synre B. the bank duet phase tormulatwe contosning noradioactuse wate. Synroc c contaning inulated high-level comnuercial waste and bynioc D). contasning simulated high. ievel deterne wastes

in par! at a nate qal DOE program on long

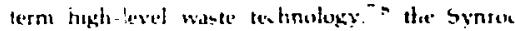

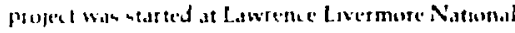
Iabordery (LLNL) in July 1070 Duting FY 10 and

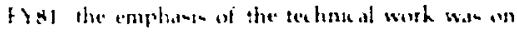

product synthesis and pertiormarice" In out program amall samples 1 - 10 to $500 \mathrm{~g}$ were sinthemised characteriecd and leathed The nups: boal was to manime the losding at the radious twe winte in a form having optemum nonkwhing chardateristis: : A paralled efturt wa- dure led at en

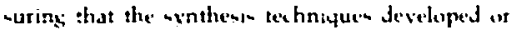

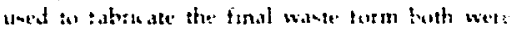

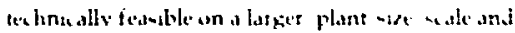
could coonomically be optrated in the envitonnen: it a remuste anvin

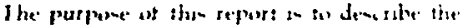

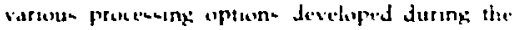
initial -t.uge of the profed :

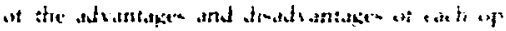

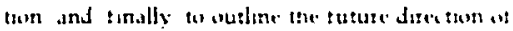

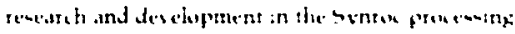
ares

\section{REFERENCE GLASS PROCESS}

The hixh level waster at the Saxannah River

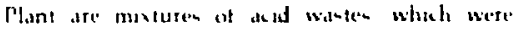
neutralized an h acese NoOH and alkaline wastem Monst of the radionuclides are contained in a precopitate as an insoluble sludge. The exception in cesium which is soluble and in the supernatant

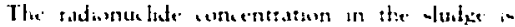

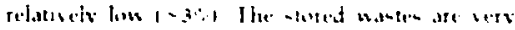

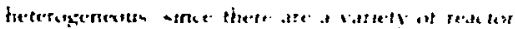

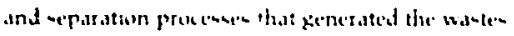

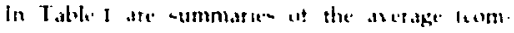

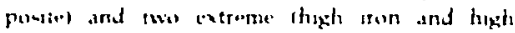

TABLE 1. Summary of average (composite) and extreme compositions (high Fe and high All of Savannah River Plant waste calcines. ${ }^{7}$ Included are only major compunents.

\begin{tabular}{|c|c|c|c|c|c|c|}
\hline \multirow[b]{2}{*}{$\mathrm{Fe}_{2} \mathrm{O}_{3}$} & \multicolumn{3}{|c|}{ Without Al semovel, nits } & \multicolumn{3}{|c|}{ With Ai remowst. wi: } \\
\hline & 53.17 & 36.13 & 5.32 & 55.90 & +7.10 & 14.80 \\
\hline $\mathrm{Al}_{2} \mathrm{O}_{3}$ & 4.78 & 28.20 & 70.05 & 1.29 & 9.21 & 50.5 \\
\hline $\mathrm{MnO}_{2}$ & 3.56 & 9.94 & 4.37 & 3.7 & 12.98 & 12.10 \\
\hline $\mathrm{v}_{3} \mathrm{O}_{6}$ & 12.34 & 3.26 & 1.28 & 12.98 & 1.25 & 3.57 \\
\hline $\mathrm{CaO}$ & 3.62 & 2.69 & 0.35 & 3.80 & 3.51 & 0.97 \\
\hline $\mathrm{NiO}$ & 9.08 & 4.47 & 0.78 & 9.54 & 5.84 & 2.17 \\
\hline $\mathrm{SiO}_{2}$ & 0.40 & 0.85 & 0.56 & 0.40 & 1.12 & 1.57 \\
\hline $\mathrm{Na}_{2} \mathrm{O}$ & 4.52 & 5.98 & 1.96 & $4-75$ & 0.03 & 5.41 \\
\hline $\mathrm{Na}_{2} \mathrm{SO}_{4}$ & 0.50 & 0.93 & 0.50 & 0.50 & 1.23 & 0.50 \\
\hline Zeolite $^{a}$ & 8.82 & 8.93 & 9.33 & B.o0 & 8.05 & 8.58 \\
\hline
\end{tabular}

${ }^{2}$ Cesium returns to the main sludge stream fixed on a zeolite having a composition appronimately $\mathrm{Na}_{2} \mathrm{O} \cdot \mathrm{Al}_{2} \mathrm{O}_{3} \cdot 5 \mathrm{SiO}_{2} \cdot \mathrm{H}_{2} \mathrm{O}$. 
aluminum) calcined wastes or equivalent fully oxidized compounds. Because of this heierogeneity. extensive head-end processing is planned. it is largely independent of the final immobilization process and includes blending. mixing screening. washing separating liquaids ani solsds. controlling pH and redor reactions. evaporsting fluids and perhapt reducing particle sire

The early glase procens reforred to an the reterense on base-ede procese is echematioslly thewn in $l_{\text {if }} \mathrm{I}$ The -upernatant containing:

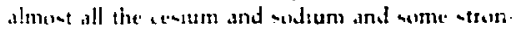
tum in sepastated trem the -ludge The certum and

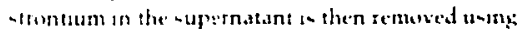

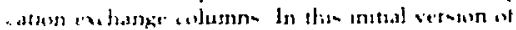

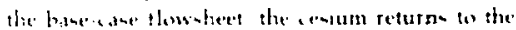

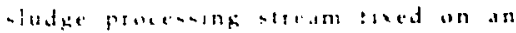
slumbnombate arolate The - erontum selusn an a

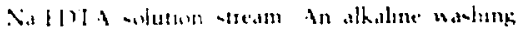

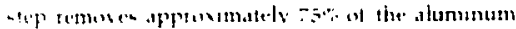

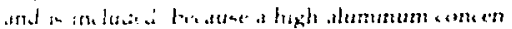

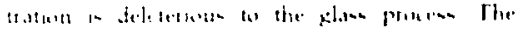

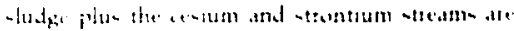

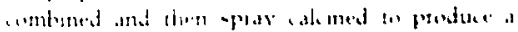

finely divided homogenuus powder. Then. the powder is mixed with glass-torming components and placed in a plass melter

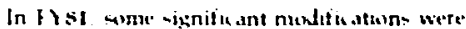

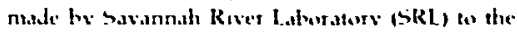

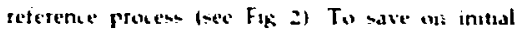
capital expenditures the -ludge and supernatint

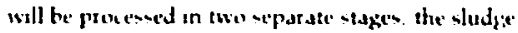

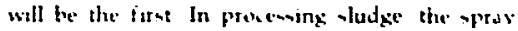

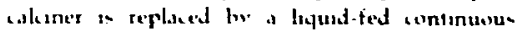

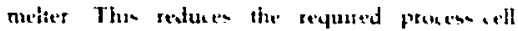
feeght and combune two nepatate -ieps then - an plitving the swiem In sdditum the base-ase

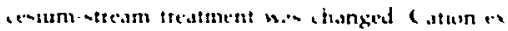

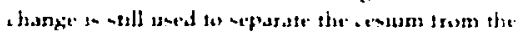

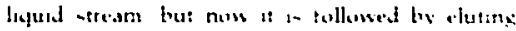
with forten ald the eluate an then ted direstlo

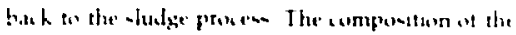

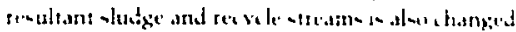

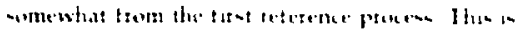

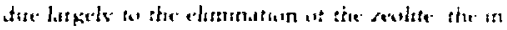

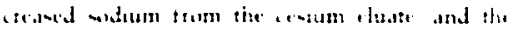

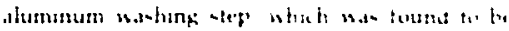

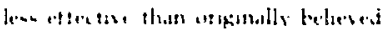

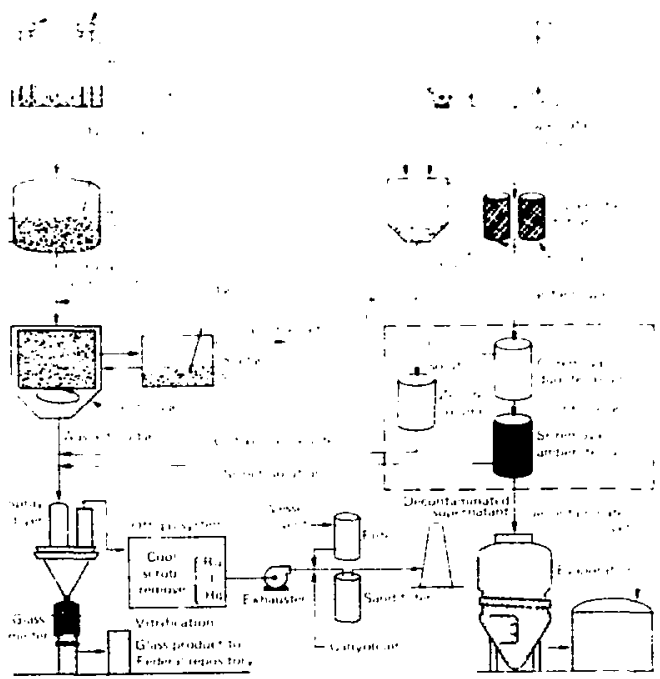

FIC. 1. Reference process (FYBO) for immobilizing Savannah River Plant radioactive waste (modified from Smith et al. ${ }^{7}$ ). 


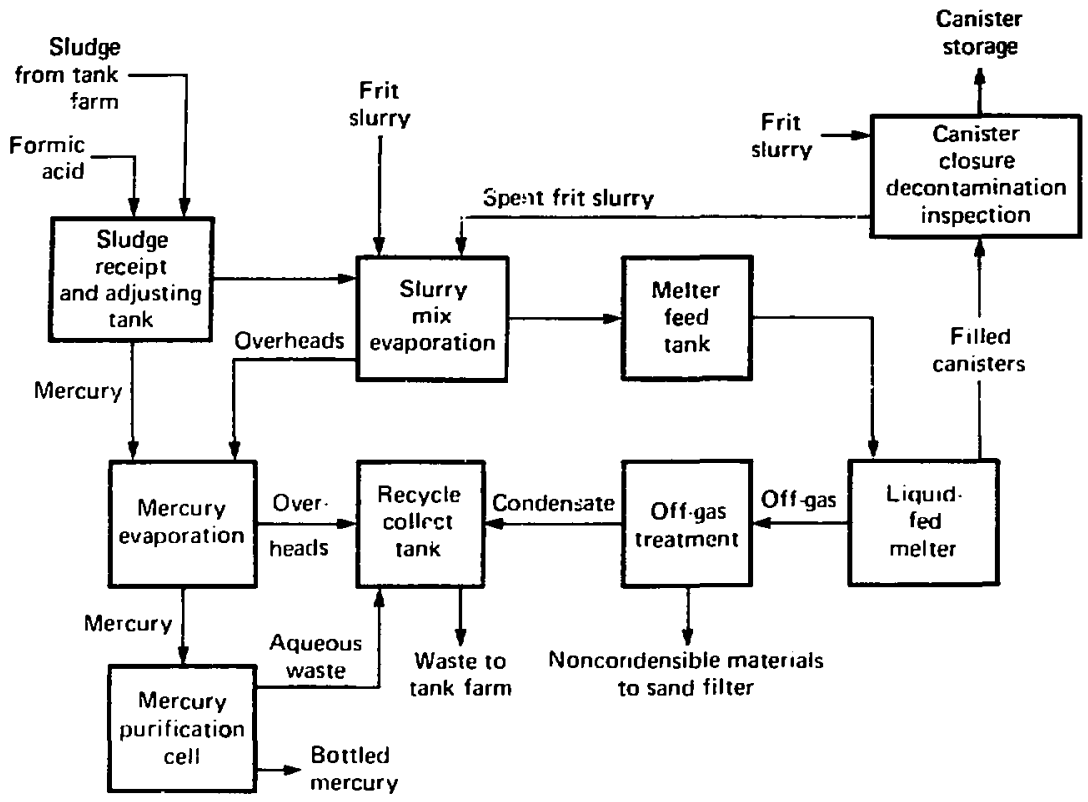

FIC. 2. Flow diagram for the first stage of the glass reference process of the detense uable procensing facility. 10 Sludge will be processed first, before the supernatunt. Io keep the initial capilal expenditures down.

\section{REFERENCE SYNROC D PROCESS}

Basia ally. Synroc immobilises the radien. nuclides as at dilute solid solution in the titanate minetals circonolite $\left(\mathrm{C}_{1} \cdot \mathrm{ZrO}_{2} \cdot 2 \mathrm{TiO}_{2}\right)$. perowshite $\left(\mathrm{CaO} \cdot \mathrm{TiO}_{2}\right)$ and a hollandite analogue $\left(\mathrm{BaO} \cdot \mathrm{Al}_{2} \mathrm{O}_{3} \cdot 0 \mathrm{TiO}\right)$. The large fraction of relatively inert components in the defense wasto reacts to form solid solutions of spinel $/(F e, M n$. $\mathrm{Ni})(\mathrm{Al}, \mathrm{Fe})_{2} \mathrm{O}_{4}-(\mathrm{Fe}, \mathrm{Mn}, \mathrm{Ni})_{2} \mathrm{TiO}_{4} \mathrm{I}$ and nepheline $\left(\mathrm{Na}_{2} \mathrm{O} \cdot \mathrm{Al}_{2} \mathrm{O}_{3} \cdot 2 \mathrm{SiO}_{2}\right)$ phases.

The distribution of radionuclides among the Synroc phases has been investigated by microprobe analysis (see Table 2 ). ${ }^{\circ}$ Both perovskite and zirconolite can incorporate the fission products and actinide elements into their crystal lattices as dilute solid solution (Radionuc lides do nus partituon intu the spinel phases.) Cesium in morporated at a dilute olid solution 12 to 5 wtol in baram hollandite.

The presence of more than a few weightpercent sodiun in the sludge negates using holiandite as a cesium host. If cesiun is to be processed with the sludge contuining several weight-pereent sodium and silicon, then nepheline or. possibly. pollucite $\left(\mathrm{C}_{2} \mathrm{O} \cdot \mathrm{Al}_{2} \mathrm{O}_{3} \cdot 2 \mathrm{SiO}_{2}\right)$ wiil act as the host. To use the more leach-resistant hollandite ds a cesium hosi would iequire a separate processing stream, unless the sodium and silicon levels in the sludge could be reduced. 
TABLE 2. Distribution of principal elements in hiph level wastes between coexisting phases of Synroc D, based on eleclton-probe microsnalysis. Symbols in parentheses indicate that small amounts of thise elements will also enter the designated phase. A possible minot metal phase incorporates Ni, S. Te, Bi, Pd, Rh, clc.

\begin{tabular}{|c|c|c|c|c|}
\hline Giranumlite & P'erounghere & 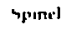 & Vepherlune & Hallendat* \\
\hline $1+$ &. & $1 r^{2}$ & $v^{\circ}$ & $10^{\circ}$ \\
\hline $\mathrm{Ih}^{4}$ & $41^{2}$ & $V_{1}=\cdot$ & $\mathbf{k}^{\circ}$ & $\mathrm{kr} \mathbf{*}^{\circ}$ \\
\hline $\mathrm{Pu}^{\mathrm{H}}$ & $\operatorname{lu}^{2}$ & $\ln =\cdot$ & $\mathrm{Rb}^{\circ}$ & $\mathbf{k}^{\cdot}$ \\
\hline $1 \mathrm{~m}^{+0}$ & $11^{2}$ & $10^{2}$ & $\mathrm{H}_{2}=$ & $\mathrm{B}=$ \\
\hline $1 \mathrm{~m}^{4}$ & $1 \mathrm{~m}^{1}$ & $\operatorname{tin}^{\prime}$ & & \\
\hline$\nu_{p}+\cdots$ & $v{ }^{x}$ & $11^{2}$ & & \\
\hline $101^{2}$ & (kसt $\left.t^{2}\right|_{1}$ & $10^{2}$ & & \\
\hline$\left.|k|\right|^{\prime \prime}, \mid$ & $\ln 11^{+1}$ & & & \\
\hline $149^{2}$ & & & & \\
\hline 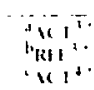 & 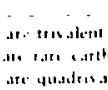 & 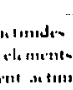 & $\cdots$ & $\cdots$ \\
\hline
\end{tabular}

The pronesere needed to produce Synou may

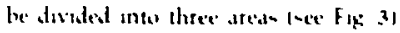

- Slurry procesomg ex blending oprav drving and erapotating:

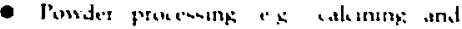
pelletiran:

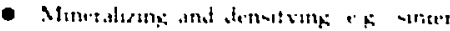

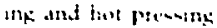

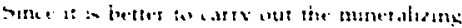

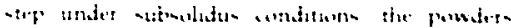

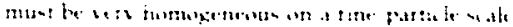

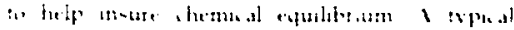

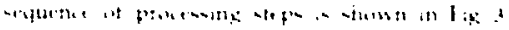

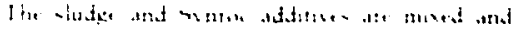

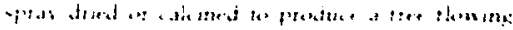

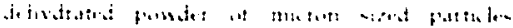

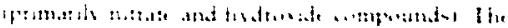

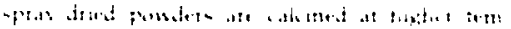

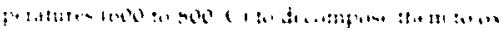

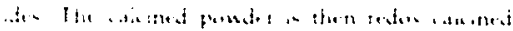

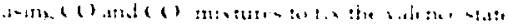

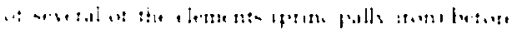

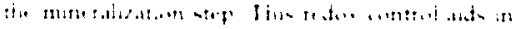

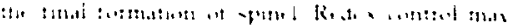

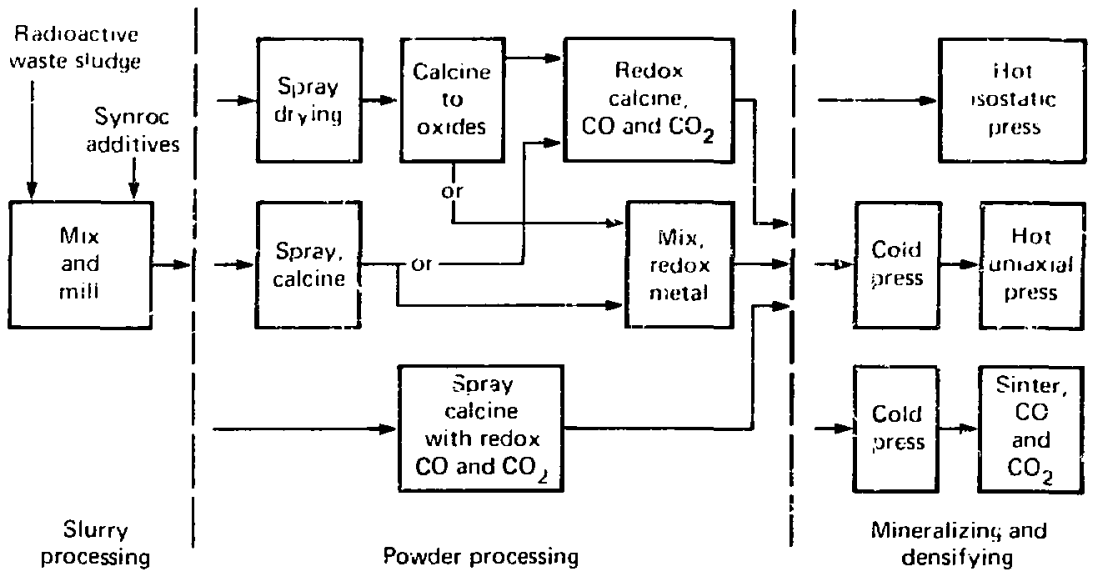

FIG. 3. Basic Synroc processing options. The process may be divided into three areas, i.e., slumry processing, powder processing, and mineralizing (densifying). 
also be done in situ using metal powders. i.e. nickel, iron, or titanium.

The mineralizing step may be carried out by hot uniavisl pressing (HLI') at temperatures at 1000 to $1200^{\circ} \mathrm{C}$ and pressures of 2 to 4 kai bintering or hot montate preseing (HIP) are ales pousible method lor this step.

During FYso a bate-t ane flow wheet sor the Synrac procese wir developed in cooperatien with

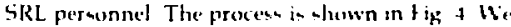

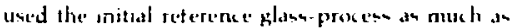

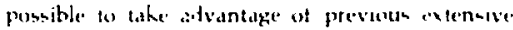

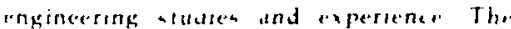

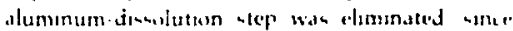

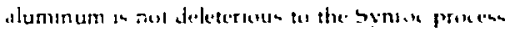

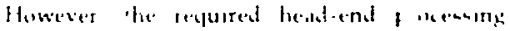

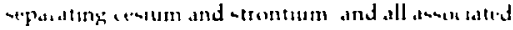

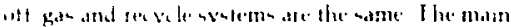

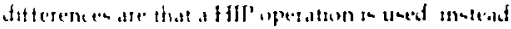

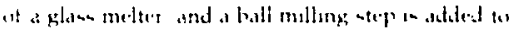

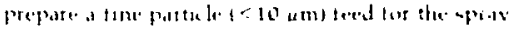

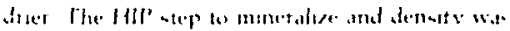

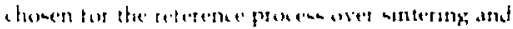

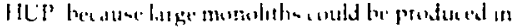
1, lewed sinterts!
Mi: visited several produation bacilities where large pieces of super allow- uned for get engene parts. are made from powder the evaluated the't iptos! operating couditions and reyurtements

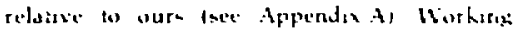
volunem of approxinatelv is $x$ st: te mperatute- to

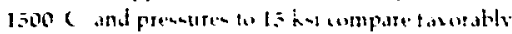
with wut reterente cune rejultment- at $2 \times 1: t$

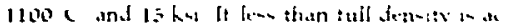

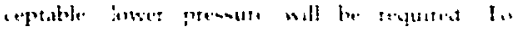

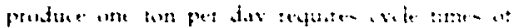

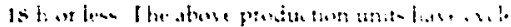

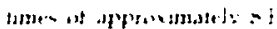

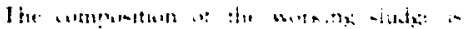

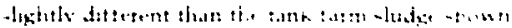

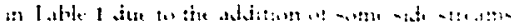

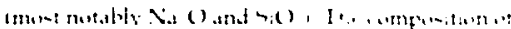

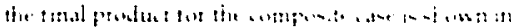

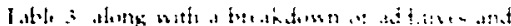

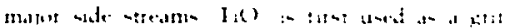

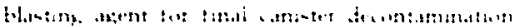

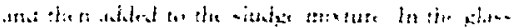

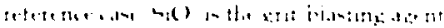

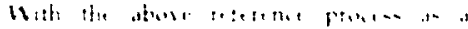

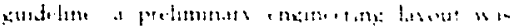

(a)

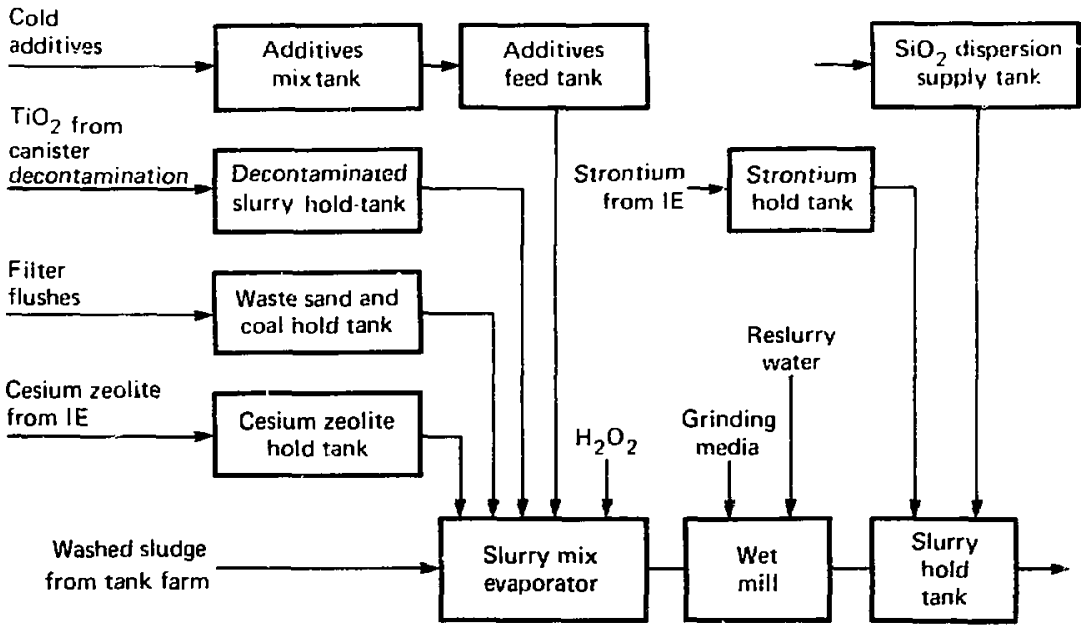

FIG. 4. A base-case flow sheet for the Synroc process. This reference process was developed in cooperation with Savannah River Laboratory personnel." (a) Feed and :lurry preparation. (b) Calcination. (c) Ceramic formation and consolidation. 
(b)

From hip

preheat

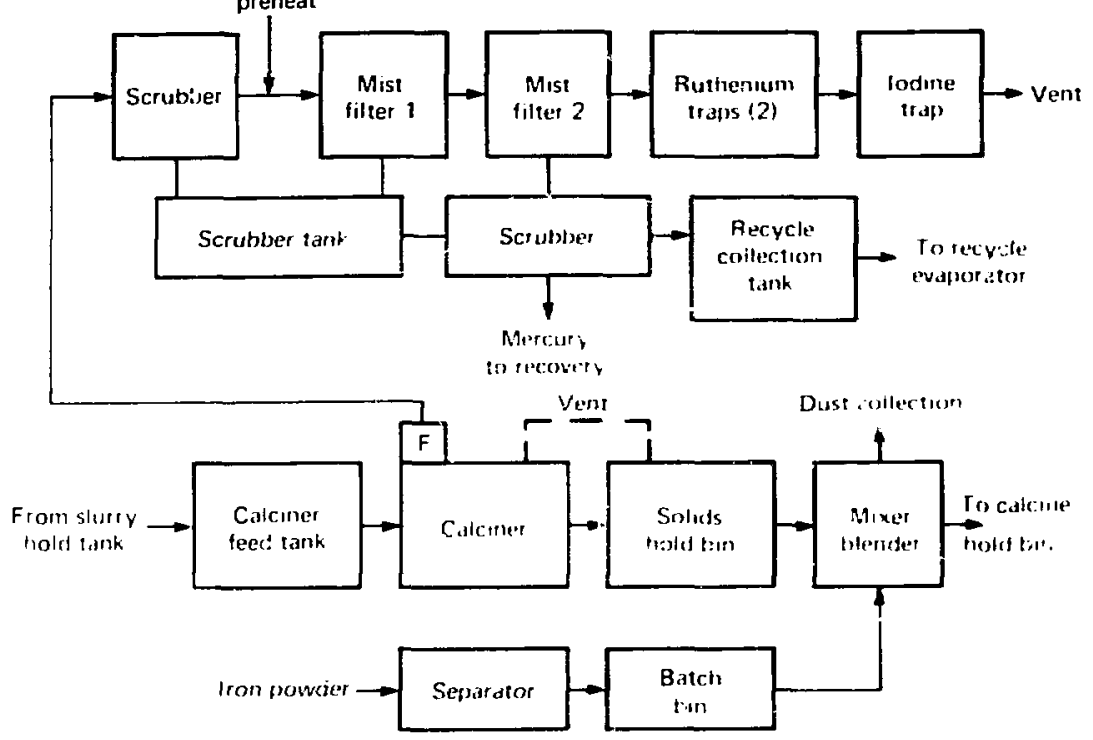

(c)

From

mixer

$\stackrel{\begin{array}{c}\text { bust collectionder } \\ \text { system }\end{array} \rightarrow \text { Reslurry } \longrightarrow \text { To slurry }}{\text { blend tank }}$

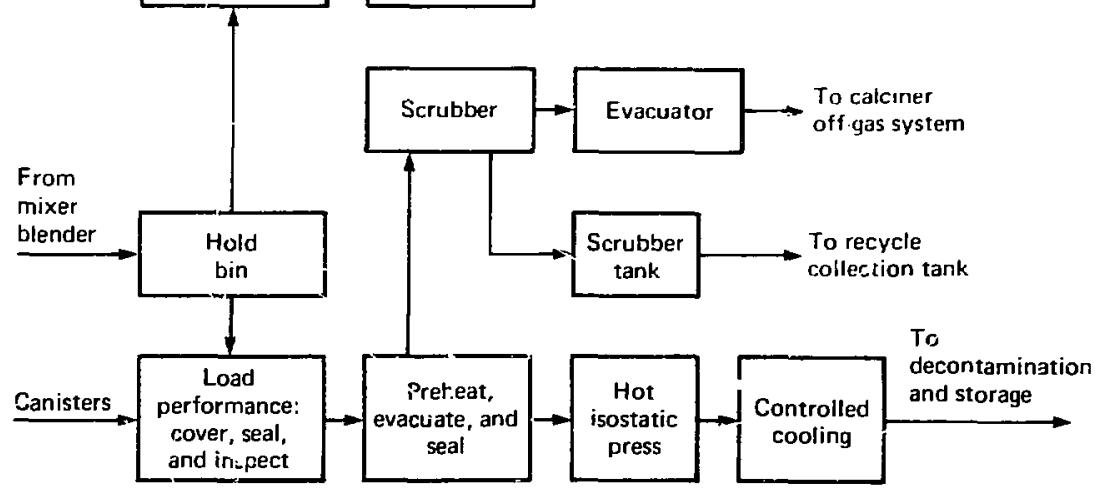

FIG. 4. (cont'd.) 
TAB:E 3. Flow rates and compositions of the major streams in the Synroc process as euuivalent oxides. The tank farm sludge is only part of the material in the system. A mujor part of the sadium and silicon comes in from the recycle streams and from filter fiushes. The final compositions resulting from the overall process are shown here.

\begin{tabular}{|c|c|c|c|c|c|c|c|c|c|c|}
\hline & \multirow{2}{*}{\multicolumn{2}{|c|}{$\begin{array}{c}\text { Total studge } \\
\text { trum the } \\
\text { tunk tum }\end{array}$}} & \multirow{2}{*}{\multicolumn{4}{|c|}{ Recode atream, tlun zalt, th h }} & \multicolumn{2}{|c|}{$\frac{\text { I lim inste of }}{\text { Total naste }}$} & \multicolumn{2}{|c|}{$\begin{array}{l}\text { I insl prendunt } \\
\text { in anterters }\end{array}$} \\
\hline & & & & & & & \multirow{2}{*}{ 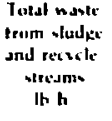 } & \multirow{2}{*}{ 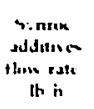 } & \multirow{2}{*}{$\begin{array}{l}\text { finl } \\
\text { Ilum } \\
\text { tute } \\
\text { II. h }\end{array}$} & \multirow[b]{2}{*}{ wt } \\
\hline & $\begin{array}{l}f \text { lins } \\
\text { itte: } \\
\text { Ih } b\end{array}$ & $n 1$ & $\begin{array}{l}\text { Grontusm } \\
\text { conctinirate }\end{array}$ & $\begin{array}{l}\text { Castumb } \\
\text { anolite }\end{array}$ & $\begin{array}{l}\text { Send- } \\
\text { Itlitr } \\
\text { tlush }\end{array}$ & $\begin{array}{l}\text { C snwter } \\
\text { Jocuntamtnstuss }\end{array}$ & & & & \\
\hline $\mathrm{l}_{12} \mathrm{Cl}_{3}$ & 20 to & 31 & & & & & 2040 & & 20 te & 213 \\
\hline $\mathrm{II}_{2}\left(\mathrm{U}_{3}\right.$ & 1010 & $11-$ & & 100 & & & $1-15$ & & 1015 & $\therefore+$ \\
\hline $\mathrm{Hnt}_{2}$ & $\checkmark+1$ & $1 a^{-}$ & & & & & $\therefore+1$ & & is & $r=$ \\
\hline$\checkmark(1)$ & $2 \because$ & $=1$ & & & & & $2-3$ & & $2-3$ & 12 \\
\hline$\sqrt{.12}(1)$ & $2+2$ & $1-$ & 221 & mi: & $0 \times n$ & & $=m+$ & & $=r+$ & $r^{-}$ \\
\hline 1,1$)_{4}$ & 104 & is & & & & & $10 t$ & & $10:$ & $\div$ \\
\hline (.1i) & $1=1$ & $\because$ & & & & & $1=4$ & $\therefore$ is & $+\infty$ & $b:$ \\
\hline $\mathrm{Sil}_{2}$ & $1+3$ & $\therefore$ & & $2+1$ & $15-$ & & $+x$ & $=0:$ & ins & $12 \div$ \\
\hline $1 \mathrm{Cl}_{2}$ & & & & & & & & +16 & +10 & $+u$ \\
\hline $1,1:=$ & & & & & & $12 \therefore$ & 120 & & $12=2$ & $1: 1$ \\
\hline$\{$ |.1.s\} & $=1 ،$ & $1,1,1$ & & & & & $\therefore 0^{\circ}$ & & 312 & $\because a^{\prime}$ \\
\hline
\end{tabular}

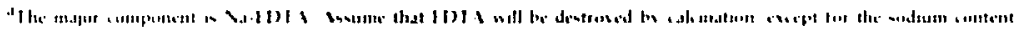

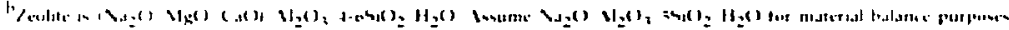

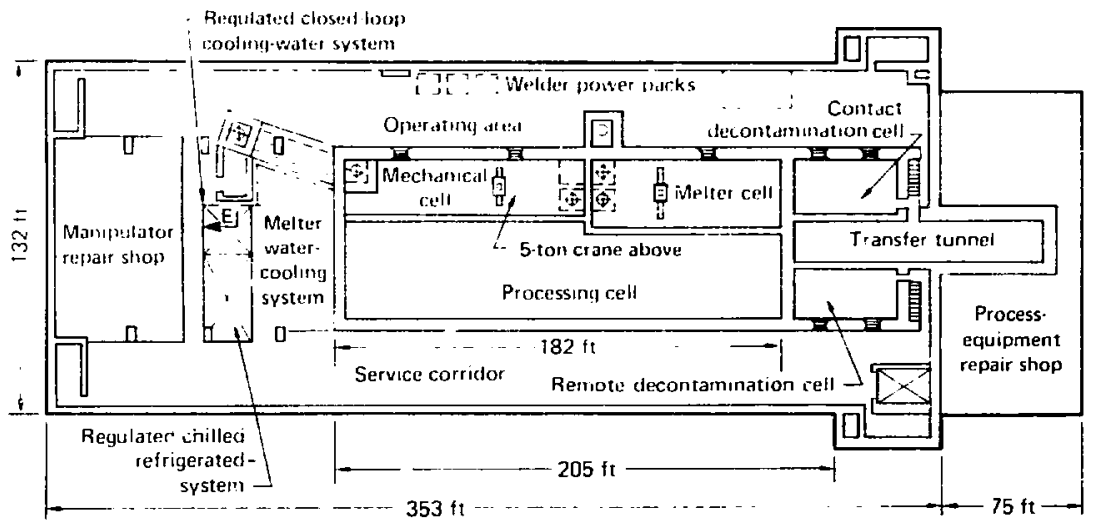

FiC. 5. Schematic of the overall building floor plan for the most recent (FYg1) glass reference process. ${ }^{11}$ 

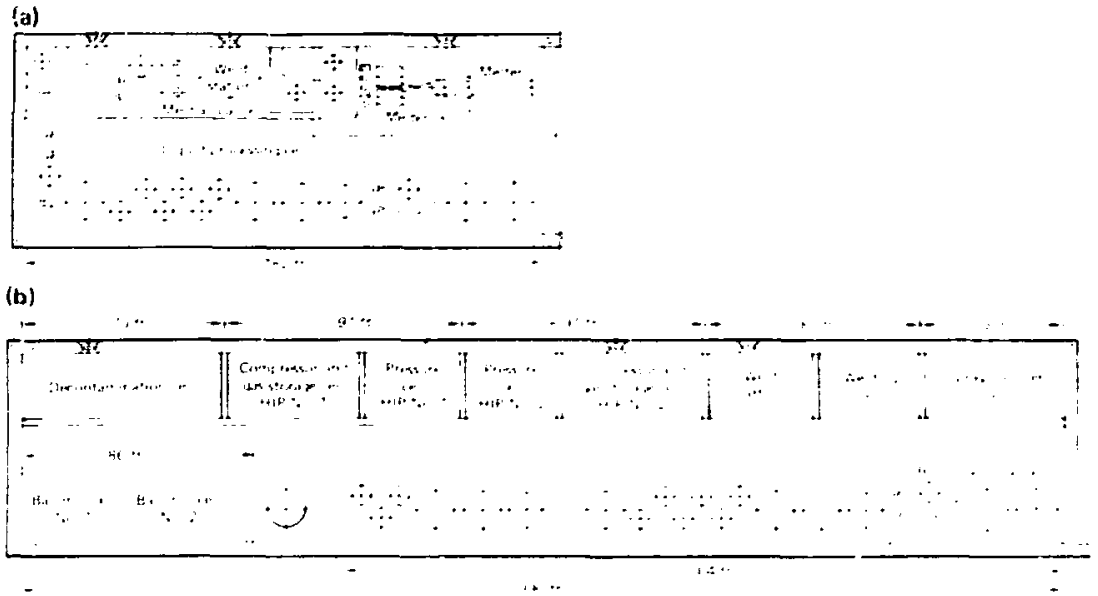

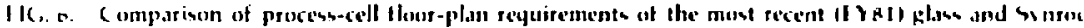

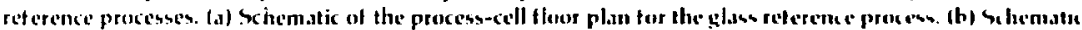
of the precess-cell tlowe plan for the bynros reterenic prosess.

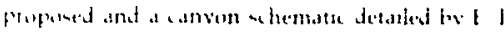

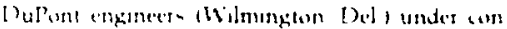

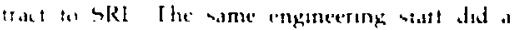

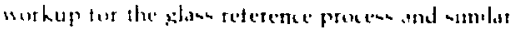

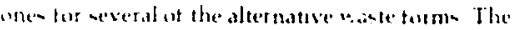

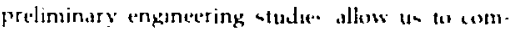
parr the glaw base-case prosese and heveral aller. native waste-form cases and will help guabe tuture research and development efforte in the processing arted.

In this report, we will not detail the preliminary engineering layout, since that will be published by SRL. Huwever. a brief summary is appropriate. The requirements of the processing cil dimensions for the latest glass and Synroc refurence processes are shown in Figs. 5 and o. The Synroc process requires a larger cell length $3900 \mathrm{vs}$ $132 \mathrm{ft}$ ). due to the increased area and volume neecied by the ball mull and HIP units. This results in a significaut difference in process cell costs. because the costs scale linearly with volume (length in our case, since width and height for the two ref erence cases are the same). The cost is approximately one million dollars per linear foot. Thus, the current reference-process cell for Synroc would

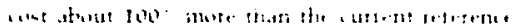

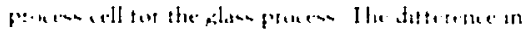

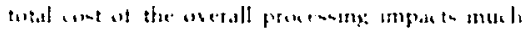

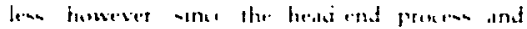

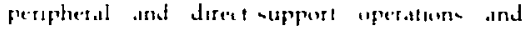

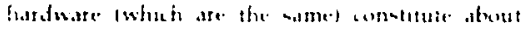
halt the sotal Thu the overall buiding and

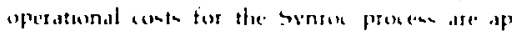
prosinately 50\% mone than that ot tie glase reference prosene the hatsen texamund the total conts of either proseres including the couts of cansters, transportation, and ultimate repository storage. However, if they are significant. Synrox could be more economical, because it his nearly three times higher waste-lodding capsity than glass and there would rey: ire fewer canisters and less repository storage space.

Two operations in the Synroc system contribute substantially to the increased process-cell length. The ball mill requires about $86 \mathrm{ft}$ and HIP units about $175 \mathrm{ft}$. Both operations have two complete systems for redundancy. A large portion of the HIP requirement results from storing the working gas in the canyon and from the related compression operation. With more detailed analysis 
and demonstration, the needed redury, aniy an the ball mill and HIP operatems nustie by telaxed tor a potential reduction of 100 ft (Other omplifuatusns

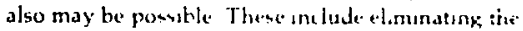
particle reduction opetation and varyong tie. calcination and redera control opetatson fate $\mathrm{Mm}$ and Mill St(p) beluw)

\section{AND MILL STEP}

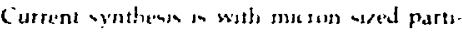
cles. The existing sludge in componed mustly of

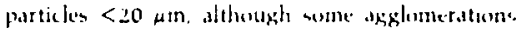
may be presens lasperes partalen aresel humbed microms in sige. ase manly atnd and coal irom tolters llushes These could tre sereened ont and the

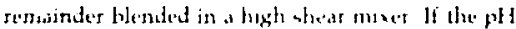

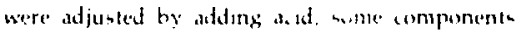

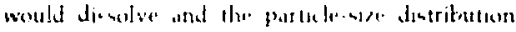

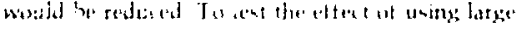

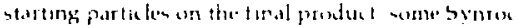

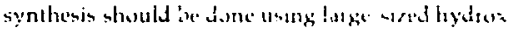
ide particles. phaps 20 and $5 c^{\circ} \mu \mathrm{m}$ 4..m? If thene

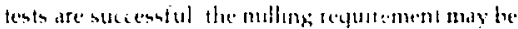
rehaxed or even climmated

\section{CONTROL STEP FOR DEHYDRATION, CALCINATION, AND RFDOX REACTIONS}

At this time, synthesis in adrited out using + ne spray drying step at $135^{\circ} \mathrm{C}$ or dehydratte the siurry and two separate calcination steps The two calcination steps are at $600^{\circ} \mathrm{C}$, to decompose to avides. and at $800^{\circ} \mathrm{C}$ under 9 lo $1, C_{2}$ to $\mathrm{CO}$ gals at mospheres for valence control of iron. manganese. and uraniu!n. An in situ redor control using metal additives (tilanium, iron, or nichel) would eliminate one calcination step, hul it reguires a metal flending -tep bysy coleining combine dehivdra. toun and deromposition ter undes and har been e. : novely investigated and develuges d:

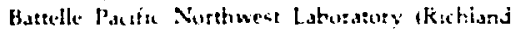

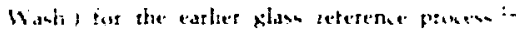
bpray caloination undes a sedice contrilled at moxphere $1 \mathrm{CO}$ and $\left(\mathrm{O}_{2}\right)$ would elimande atest

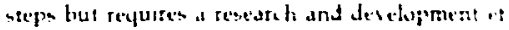

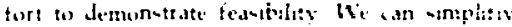

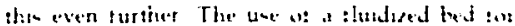

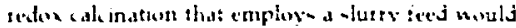

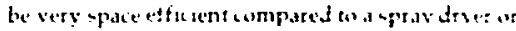

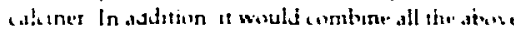

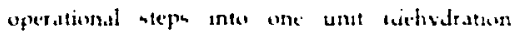

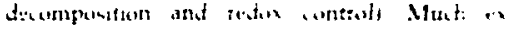

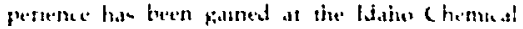

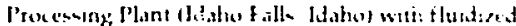

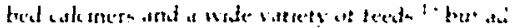

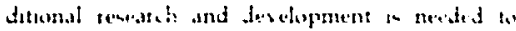

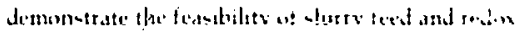

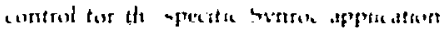

\section{MINERALIZATION INVOLVING HIP, SINTERING, AND HUP}

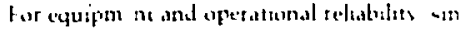
tering is the most conventional snd well understowd at the three densitying uperations HUP and Hit? under modest pressures each readly gives >00\% densification at temperatures lower than reguared for sintering. The equipment and ampleaty of operation fo! high production rates uning HIP or HUP however are significantly greater. For HLP there are concerss of die and puncii lifetinter and operational reliability. For HIl' there is the atorage requirement of harge working gas volumes as well as questions of equipment and uperational com. plexity. Research and develupment of the process applitation of all these densification options will continue. 


\section{REFERENCES}

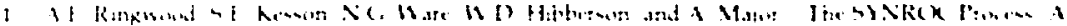

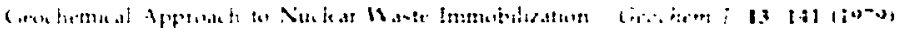

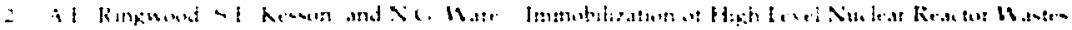

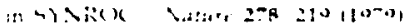

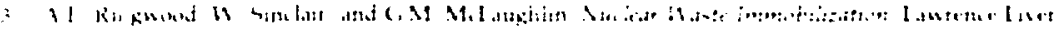

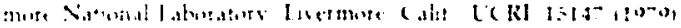

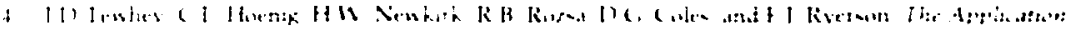

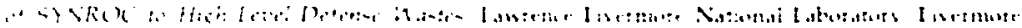

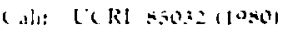

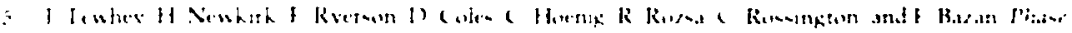

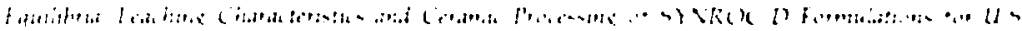

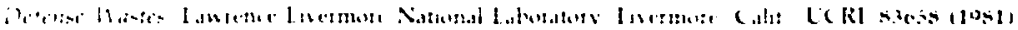

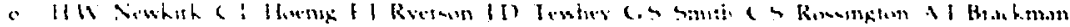

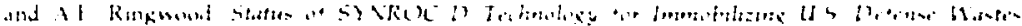

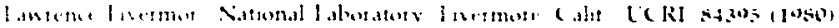

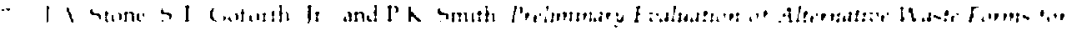

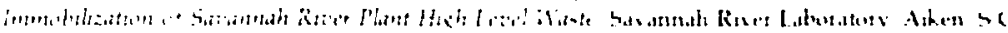

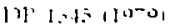

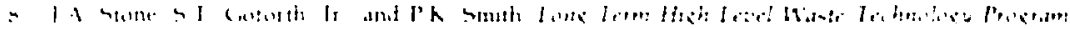

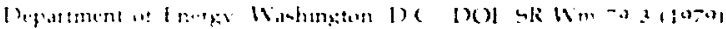

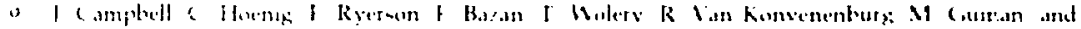

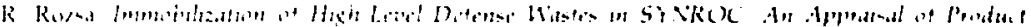

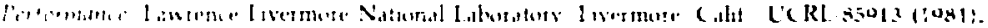

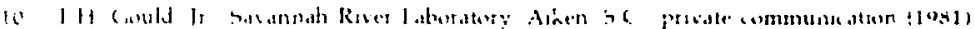

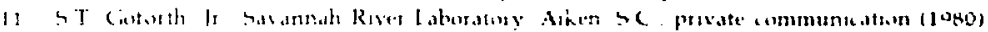

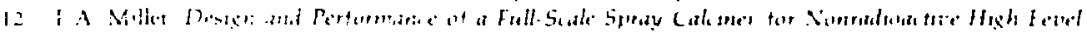

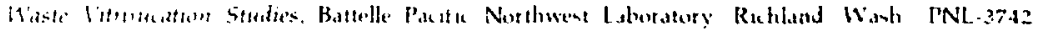
(1)

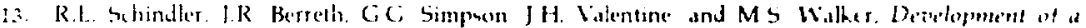

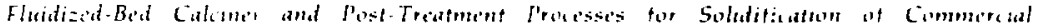

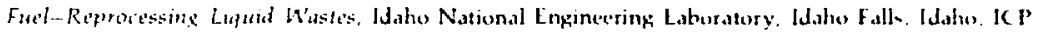
$1130(10 \div 7)$. 


\section{APPEIVDIX A. TRIP REPORT OF VISITS TO HIP FACILITIES}

lune 0 , 19 ho

C\&C; $80-27$

To John rewher

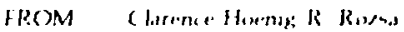

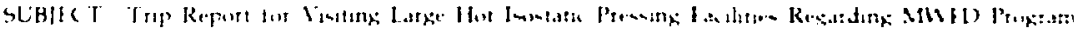
Jine P'ermal Ma: 10 21 1000

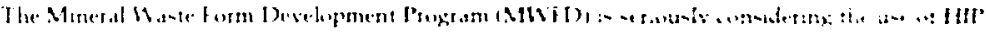

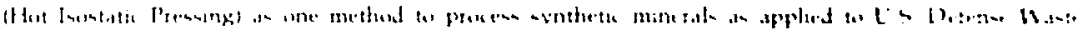

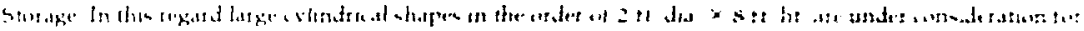

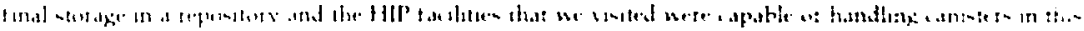
-Hetange

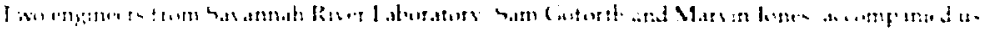

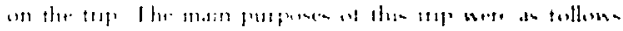

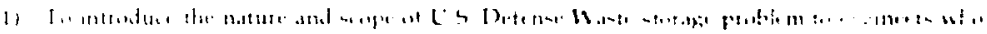

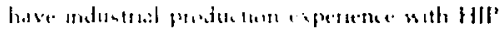

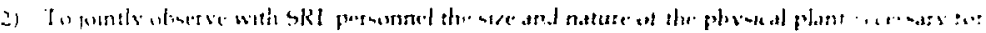

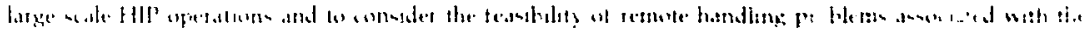

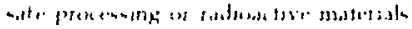

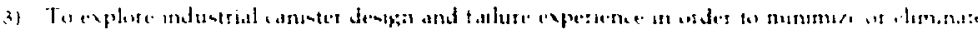

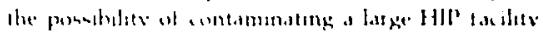

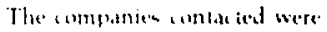

1) Wymun Cindun (orp'

Wioraler Rousd

N Ciraltun MA

2) Industrisl Material, Texhndong In

155 River Strect

Anduver. MA O1sto

3) United Texholugies Rencarch C (noter and Pralt-Whatney Corp

Silver Lane

Eant Ifartford. CO dolos

The HIP facilitirs visited were of wo types Buth Wyman-Gordon ans? Pratt-lihiener have Ast $A$ units which are vertical wire wound vestels with wire wound frame supported end ilouser. The IMT unitare verticial forged vesiels with threaded end clusures manubatured by National Forge Corporation.

The ASEA units are the largest HIP facilities in cxistence. The furnaces enclosed in the presure vessel have an availsble working space approximately 47 inches dia. $X 00$ inches height and are capable of achieving a temperature and pressure of $2300^{\circ} \mathrm{F}\left(1200^{\circ} \mathrm{Cl}\right.$. $20 \mathrm{KSI}$ respectively Temperature variatiun: throughout the furnace cavity are held to less than $\pm 25^{\circ} \mathrm{F}$ using a four zone furnace. Replacement custs fors a new furnace are about $\$ 300,000$.

Because of size and long cooling times, the furnaces are never cooled below $1550^{\circ} \mathrm{F}\left(850^{\circ} \mathrm{C}\right) \mathrm{during}$ normal operation. The work load is prehcated in a separate furnace and then bottom ioaded into the main HIP furnace. Finished work is unloaded at $850^{\circ} \mathrm{C}$ and slow cooled in a scparate facility.

These ASE.A units had been in operation about 2 years. Over that period of time $\sim 14 \mathrm{c}$ heating cycles had been accomplished. During that time the furnace had to be repaired 3-4 times. Fur uáte failure was due to the unpredictable expansion after severa' cycles of an insulating mantel over the furnace. Design 


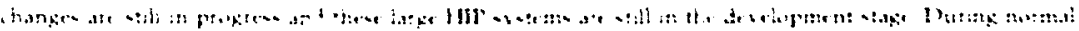

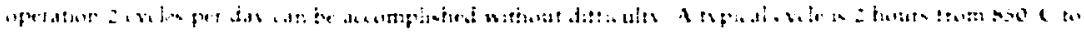

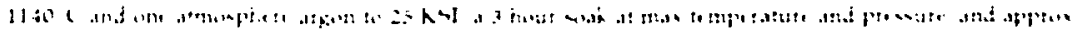

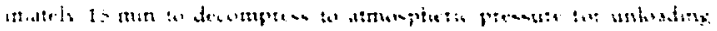

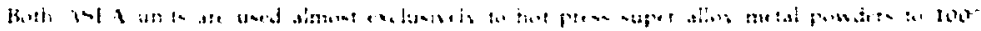

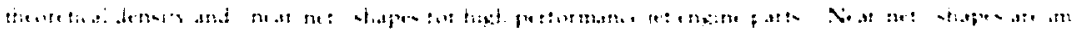

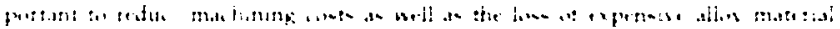

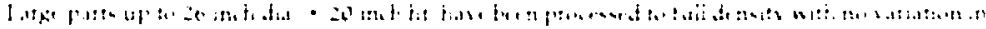

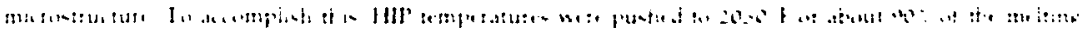
fint

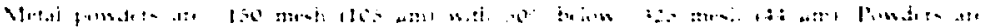

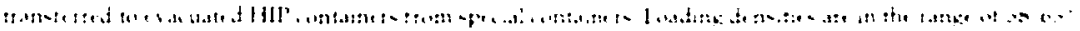

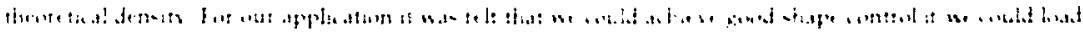

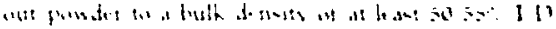

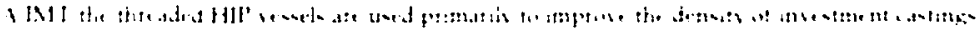

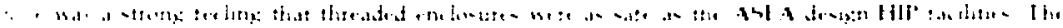

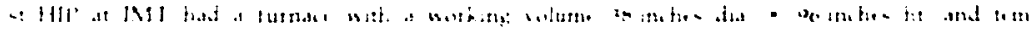

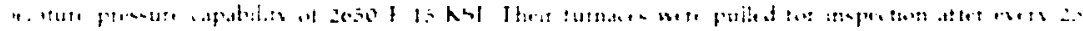
, i. li...

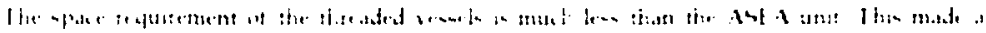

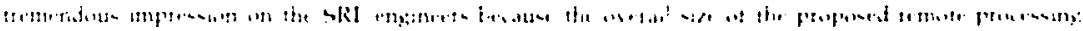

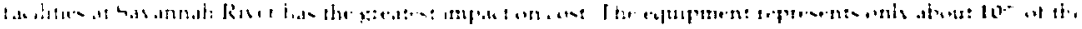
$1,+1+1+\ldots+1$

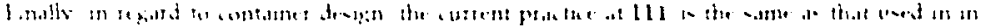

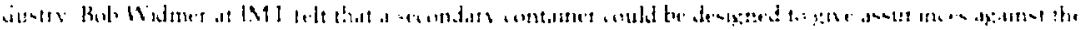

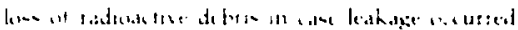

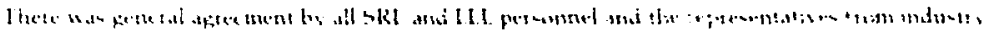

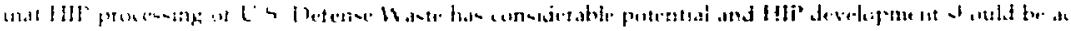

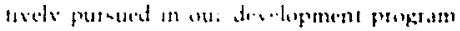

